\title{
NARRATIVA ÁRABE, OTRA INTERPRETACIÓN
}

Por

MARCELINO VILLEGAS

Suele decirse que la literatura árabe clásica produjo una narrativa insuficiente. Afirmación tan obviamente falsa, cuando existen, verbi gratia, Las mil y una noches y Calila y Dimna, dimana de sendos errores de perspectiva. El primero proviene de suponer que las formas narrativas modernas son universales; el segundo, de la aplicación mecánica de normas que falsean el libre ejercicio de la inventiva y la expresión.

Régis Blachère (1) y Mohammed Ferid Ghazi (2) han sugerido o propugnado que la opinión de los orientalistas quizá se deba a la multitud de textos narrativos árabes perdidos. El razonamiento me parece fútil al lado de la importancia e incluso el volumen de lo conservado. Puede ser válido, sin embargo, junto a otras evidencias, para apoyar otra idea, la opuesta a la que reproduzco en las primeras líneas de mi trabajo, a saber: que la cultura árabe es fundamentalmente narrativa y tiende a transformar todo hecho en relato, pues el relato es su único medio de preservar la apariencia, interpretarla y extraer de ella modelos de comportamiento.

1Otra cosa es si la narrativa árabe clásica sigue - como la accidental moderna sigue - el principio de la mímesis, y si es idéntica la noción de espacio narrativo que adoptan una y otra. Luego me referiré a esto).

La mil y una noches, Calila y Dimna y diversas siyar fueron conocidas en occidente bien en la época medieval, bien en la moderna, bien en el siglo

(1) Histoire de la Littérature arabe des origines à la fin du XVe siècle de J. C. (Maisonneuve, París, III, 1966, p. 737 y ss.)

(2) "La littérature d'imagination en arabe du $\|^{e} / V I I I^{e}$ au $V^{e} / X I^{e}$ siècles», en "Arabican, IV (1957), especialmente pp. $175 / 178$. 
pasado. Las dos primeras dieron impulsos decisivos al desarrollo de la narrativa en Europa y han sufrido un proceso de apropiación que las ha transformado de obras árabes en obras universales. Y así, privada de ellas, la superficie de la narrativa árabe ha quedado visiblemente mermada. No ha habido robo, sin embargo, sino adquisición de un bien descuidado -e incluso desdeñadopor el dueño. Porque es cierto que, en el concurso de sus géneros narrativos, los intelectuales árabes han tenido en poco los de pura imaginación.

El desdén proviene de que la teoría árabe - teoría más que literaria vitaljuzga inferior esa clase de inteligencia.

Abdel-Aziz Abdel-Meguid (3) inventaría doce términos árabes que designan otros tantos tipos de relato. Los examina sin ningún modo de orden visible (alfabético, temático, formal u otro) ni clasificación. Los doce términos que Abdel-Meguid estudia son, en el orden en que él los da, los siguientes:

1) Qișșa, 2) Sira, 3) Hadīt, 4)Hikāya, 5) Samar, 6) Jurāfa, 7) Usțūra, 81 Riwāya, 9) Nādira, 10) Jabar, 11) Mațal, 12) Màqāma.

Estos doce términos pueden remitirse a cinco clases o formas de relato. Para agruparlos he tenido en cuenta la proximidad y fidelidad de cada uno a la noción de verdad según la teoría árabe.

Del examen y agrupación de los doce tipos de relato surge la siguiente precisión: siendo la cultura árabe profundamente dada a relatar impone asimismo al libre curso del deseo de relatar rigurosas trabas para que el relato no pase del territorio de la verdad al de la fábula. La norma es ésta: todo relato debe ser verdadero, es decir, debe fijar y dar cuenta de algún aspecto de la realidad lentendida como hechos que materialmente se han producido y como manifestación de la realidad superior) de acuerdo con cinco reglas:

\section{DEBE SER BREVE, COMPLETO, DENSO, CIENTIIFICO Y EJEMPLAR.}

Breve, porque sólo tendrá sitio en él lo esencial; completo, porque incluirá todos los rasgos pertinentes de la idea, la situación o la persona; denso, porque fijará el contenido en fórmulas preceptivas y fáciles de retener; científico, porque proporcionará los datos que permitan reinsertar el relato en la realidad $y$ tener garantía de que procede de ella; ejemplar, porque contendrá modelos de comportamiento.

La forma perfecta de relato es, pues, el hadit profético: por lo noble y cierto de su referente, por lo riguroso de la técnica (tema: tarŷuma; inserción en la realidad: isnād; ejemplo y norma: matnl. La razón del relato es lo necesario de la doctrina.

(3) The Modern Arabic Short Story. Its Emergence, Development and Forn (Dar al-Maaref, El Cairo, s.f., pp. $1 \uparrow-27)$. Abdel-Meguid se remite al artículo «Hikāya», de D. B. McDonald $\left(\left.E\right|^{\uparrow} 11,321-324\right)$. Apenas nada añade el artículo "Hikãya», de Charles Pellat $\left\langle E^{2}, 111,379-384\right)$ 
Las otras formas narrativas aceptables son variaciones menos rigurosas del hadìt o con referente menos noble o real que el que hadīt tiene; al-Ŷăhiz suele introducir sus relatos con una especie de isnād (el nombre del testigo de los hechos y/o el de los que se lo refirieron) (4); Ibn Batțutta hace lo propio en su forma más sencilla ("yo fui testugo" o "conocí a quien lo vio»); y otro tanto ocurre en los libros de tabaqāt y ajbār sobre poetas o sabios.

El jabar, pues, es la forma narrativa que va más a la zaga del hadit profético: tiene, proporcionalmente, tarŷuma e isnād y sólo el referente del matn es inferior o más incierto en su enseñanza que el de aquél. Por otra parte, la observación de la técnica (breve, completo, denso, etc.) es estricta:

«Una vez declamó ante Marwān ibn Abī Hafsa un grupo de poetas. Y a medida que iban haciéndolo Marwān decía: "Tú eres el mejor poeta». Hasta que, después de repetirlo muchas veces, se corrigió y dijo: "Todos sois el mejor poeta» (5).

En cualquier caso, para ser admisible, o sea, para entrar en el espacio de la literatura y no caer en el de la subliteratura, el relato-cualquiera que sea su forma - debe compensar la pérdida de calidad del referente con la veracidad, el rigor formal y algún otro componente ennoblecedor que le sea propio: el ingenio (nādira), la reflexión (mațal), la riqueza de estilo (maqāma).

El nacimiento de nuevos géneros, como la maqāma y la hikāya (6) es posible, paradójicamente, porque se refieren a personas sin moral: sólo ellas (y no las honradas) tienen historia, una historia que exige una forma narrativa nueva.

La maqāma es, por otra parte, un género de géneros, ya que, sobre la base costumbrista que la sustenta, se desarrolla a veces como relato de aventuras ( $n .{ }^{\circ} 6$, asadìa), caballeresco (n. ${ }^{\circ} 51$, bišriya), de tesis ( ${ }^{\circ}{ }^{\circ} 25$ y 26 , $\hat{y} \bar{u}^{c} \overline{T y} a$, juțbiya), lexicográfico ( $\mathrm{n} .^{\circ} 29$, hamdāniya, que retoma una forma de expresión tradicional, presente ya en el libro de Calila y Dimnal, de crítica literaria (núms. 1, 15, 29, 44). La maqāma 7 , gaylānìya es un jabar sobre Dū-rRumma, la 21 (mawșilīya) una nādira de humor negro. La 19 (sāsānìya), por su parte, trae un precedente del patio de Monipodio en Rinconete y Cortadillo.

Además, la maqāma utiliza, invirtièndolo, (y es difícil saber si lo hace por saturaçión o con intención blasfema voluntaria) el patrón del hadít profético, ya que su esquema formal se reduce a:

\section{1) Presentar un personaje que es autoridad en determinado tema.}

\footnotetext{
4) Libro de los avaros (trad.: Serafín Fanjul y Alcaén Sánchez) (Editora Nacional, Madrid 1984, pp. 88-92, $95,97,107,111,131$, passim).

(5) Ibn Raša, al-cumda (El Cairo 1925, 1, 56). Citado por Amjad Trabulsi, La critique poétiques des Arabes (Damasco 1956, p. 253 (texto árabe), p. 5 (traducción francesa)

(6) Pienso en la Hikāyat Abī-l-Qāsim, de Abü-l-Muțahhar al-Azdĩ. En este título debe entenderse hikāya como imitación, cuadro de costumbres.
} 
2) Transmitir literalmente palabras de ese personaje, fragmentos de su doctrina.

Ahora bien, esto lo hace oponiéndose al hadit en dos puntos:

1. ${ }^{\circ}$ El personaje que presenta es autoridad en maldades.

2. $\left.{ }^{\circ}\right)$ El estilo que lo relata y transmite sus palabras no es breve, completo, denso, científico y ejemplar, sino dilatado, fragmentario, difuso, caprichoso y obsceno.

Cuando el elemento compensador es exterior al relato, esto es, si no interesa al referente, la composición ni el estilo y procede del entorno o es circunstancial, queda ya muy próximo a lo rechazable, a la subliteratura: la antigüedad y el prestigio de la época en que nació ennoblecen al samar, la vitalidad popular hace lo propio con la hikāya len el sentido más habitual de cuento maravilloso) y el trasfondo histórico con la sira, tres formas de relato que, según la norma, caen por principio en la falsedad (esto es, en la falta de veracidad) de la juārfa y la usțūra.

La vitalidad de la hikāya y su pervivencia, siendo como es un tipo de relato rechazable, puede explicarse por el hecho de que tanto sus productores (mujeres) como sus consumidores (niños) están al margen. Esa marginalidad explica que multitud de hikāyāt, textos orales como eran, hayan pervivido hasta el momento en que los juicios de valor se han modificado y han empezado a ser puestos por escrito, cosa que no ha ocurrido con el corpus de otras clases de relato rechazable. Esa misma marginalidad ha sido la que ha preservado a las autoras de hikāyāt de la idea de estar formando ídolos y que Dios podía pedirles darles vida el Día del Juicio; así, la hikāya ha inventado realidad en vez de fijar hechos y dichos reales.

La legitimación de la sĩra, en marcha desde hará unos cuarenta años, sè ha producido a costa de crear virtualmente un género nuevo en el que los aspectos imaginativos se difuminan mientras que los aspectos verídicos (históricos, ideológicos) quedan subrayados y se erigen una vez más en criterios de dignidad (7).

Creo improbable que los términos ustūra y jurāfa designaran en época clásica tipos específicos de relato. Se trataba, más bien, de vocablos para la valoración crítica. Usțura aparece nueve veces en el Corán, siempre en plural (8) y como sinónimo de falsedad (procedente de un mundo otro, añadiría), pero en fechas recientes ha adquirido el valor de mito, leyenda (9), en sentido

(7) Véase el prólogo de Fãrūq Jūršĩd a su edición abreviada de Sayf b. Dĩ Yazan (Dãr al-kātib al-'arabit, E Cairo 1967, 2. ${ }^{a}$ ed., pp. 12, 18 y 20). También Turayyā Manqüš, Sayf b. Di Yazan bayna l-haqīqa wa-l-usțüra (Wizārat aț-țaqafa, Bagdad 1980$).$

(8) Véase Abdei-Meguid, op. cit., p. 20, nota 1.

(9) Un ejemplo de empleo negativo de ustüra en Jưršĩ, op. cit., p. 13. 
tanto positivo y denotativo (los mitos griegos) como negativo y connotativo (falso prestigio, cosa respetada erróneamente). Jurāfa sigue siendo, sin embargo término de valoración negativa equivalente a cuento increíble, descabellado; tontería, conseja. Esta palabra, por lo despectiva, ha caído en desuso en español como término para designar una forma narrativa precisa. Julio Casares la define así: "Fábula, patraña, narración falsa, mentira» (10). Algo parecido debió ocurrir en árabe con jurāfa, ya que desde muy antiguo se utilizó para calificar al relato sin fundamento real (11).

De las doce palabras referentes a tipos de relato que recoge Abdel-Aziz Abdel-Meguid me he referido a diez. De las dos que faltan (qișșa, riwāya) hablaré al esquematizar las relaciones de todas ellas, ya que se trata de términos generales, que hacen referencia al acto del discurso, y que, por lo tanto, funcionan de manera polisémica o neutra.

Distribuyendo las doce formas de relato por afinidades y de superior a inferior o de positivo a negativo, obtenemos la siguiente clasificación:

A. Polo positivo.

I. Formas superiores, sagradas o que expresan el poder, su estructuración y las verdades esenciales. Su identificación con la verdad es completa.

1. Hadìt (12).

2. Jabar.

II. Formas inferiores al no ser positivas en lo esencial (que es profano), sino en lo accesorio (ingenio, estilo, calidad didáctica). Son formas cultas de relato. Su identificación con la verdad es casual, incompleta; o se produce en niveles inferiores.

\section{Nādira es un jabar de carácter privado y festivo.}

4. Matal (se define por formalizar modelos de comportamiento sin reducirlos a norma; su técnica puede ser la de cualquier otra forma narrativa, incluso la de la hikāya y la jurāfal.

5. Maqāma (hikāya ennoblecida por la ambición literaria y el propósito testimonial - fijar una realidad-o de denuncia - modificarla-).

(10) En su traducción inédita de Calila y Dimna José Antonio Conde vierte mațal por conseja. Cfr. Traducciones del griego y del árabe, manuscrito $9 / 5968$ de la Real Academia de la Historia, p. 78 y ss.

(11) Tanto McDonald, op. cit., p. 322 como Pellat, op. cit., p. 381 mencionan ef texto en que al-Mas ${ }^{\circ} \overline{d i}$ traduce el persa afsāna, nombre de los cuentos de Las mil y una noches en esa lengua, por jurăfa. Pellat incluye también el relato que explica el origen y sentido de esta palabra.

(12) Como relato profano, en cuanto está ligado a la conversación o diálogo, a la relación de un incidente o novedad, hadît está ligado a la maqāma (cfr. el Hadît de Ibn Durayd y el Hadīt 'T̃sà b. Hišām, de alMuwaylihī). Recuérdese que Américo Castro propugna que novela es derivación semántica de hadit, España en su historia (Crítica, Barcelona 1983, 2. ${ }^{a}$ ed., pp. 632-635). 
B. Polo indiferente.

III. Formas neutras, relacionadas con el discurso en sí, con el dar forma verbal a hechos sucedidos o por suceder y con la expresión de espectativas y juicios. Por ser las formas de relato más neutras y menos definidas en la época clásica han sido adoptadas por los contemporáneos para designar las formas narrativas nuevas, cuento y novela. Relato tiene en español el mismo carácter neutro y polimorfo; y es también de uso reciente (12 bis).

\section{Oișșa.}

7. Riwāya.

C. Polo negativo.

IV. Formas populares, aleatoriamente aceptadas y que raramente pierden su carácter subliterario.

8. Samar (relato de variado registro, ennoblecido por la antigüedad y la autenticidad).

9. Usțūra (jurāfa ennoblecida por el contenido y la profundidad. A veces, también, por su calidad inventiva. Todo ello en época moderna).

10. Hikāya (relato por lo general maravilloso y con elementos cómicos; jurāfa ennoblecida por la vitalidad y la autenticidad profunda).

11. Sirra (jurāfa ennoblecida por el trasfondo histórico y por su propósito de exaltación nacional).

$V$. Formas rechazables. Más que referirse a un género preciso con reglas y características propias, es término valorativo que puede aplicarse a obras equivocadas de cualquier clase. La misma función tiene en ocasiones usțūra, que, como ya vimos, tiene en el Corán el significado de «historias que no nos conciernen». Tanto jurāfa como usțūra tienen a su vez connotaciones que significan jerigonza. Șabrī Muslim («al-Aqlām», abril 1981, p. 12) ha tratado de expresar la nueva valoración de este tipo de relato mezclando términos: hikă ya juräfīya.

\section{Jurāfa.}

¿Cuántos de estos tipos de relato tienen paralelo en la literatura occidental? Al menos cuatro: hadít y jabar me parecen relacionados con la literatura

112) bis) al-Muwaylihī, Hadìt 'isà b. Hišām (Dār al-ŷanūb, Túnez 1984, p. 50) utiliza qișșa con el sentido

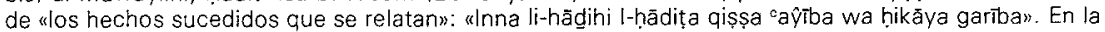
p. 54 hace lo propio con riwãya. En Cervantes tiene ese valor cuento. Por ejemplo, en "La señora Cornelian (Novelas ejemplares, Espasa Calpe, Madrid 1967, 7. ${ }^{\text {a }}$ ed.1: "En el camino os contaré un extraño cuento que me ha sucedidos (p. 191). 
de testimonio y de reportaje; matal con la didáctica, de tesis y psicológica; maqāma con el cuadro de costumbres; nādira con el chiste.

De todos modos los doce términos comentados no agotan la riqueza de formas de relato que encierra la literatura árabe, dado que, a veces, una sola palabra designa varias formas de relato, que en occidente tienen su término propio.

Matal, por ejemplo, que es el único nombre utilizado en el libro de Calila y Dimna, corresponde, además de a ejemplo, modelo y refrán, a varias formas de relato de una misma clase, pero con características propias: fábula, apólogo, alegoría, parábola y símil, según que los personajes principales sean bestias o humanos, que la acción contenga un discurso simbólico en clave, que se reduzca a una especie de instantánea o lema, apenas esbozado narrativamente, o a esa misma ínstantánea o lema presentada no en acción, sino como visión paralela de dos realidades semejantes.

Los fragmentos narrativos abundan en las obras no narrativas árabes de la época medieval. Son relatos que, pese a su vitalidad y su riqueza de invención, no se ajustan a las normas de la narrativa moderna, sin por ello carecer de sugestión fabuladora, dominio formal o complejidad de significado.

Voy a examinar ejemplos de tres obras (uno de cada una), sometiéndolos en cada caso a tres interrogantes:

1. ¿En qué se diferencia la forma del relato de la que es habitual en la narrativa moderna?

2. ¿Por qué no supo o no quiso el autor desarrollar su relato en la forma habitual en la narrativa moderna?

3. ¿Puede rehacerse el relato de acuerdo con las reglas de ésta? $Y$ en tal caso, ¿de qué modo puede fecundar su patrimonio narrativo a la ficción árabe actual?

El primer ejemplo procede de una obra miscelánea que a sí misma se concibe como tratado de magia, aunque a su vez contiene partes filosóficas, astrológicas y de curiosidades ('âyā'ib wa garā'ib). Se trata de Gāyat al-hakìm o Picatrix, escrita en al-Andalus, probablemente durante el siglo VIXI. El texto que voy a comentar aparece en el tratado segundo capítulo once (13). Dice así:

"Tienen tantas cosas maravillosas que si las aportara se hiciera el libro excesivamente largo. Entre ellas la cabeza en que creen sus más importantes sacerdotes y que ponen junto a la cabeza del dragón. Ello es que buscan un

(13) Pp. 167-169 de la versión española hecha por mí (Editora Nacional, Madrid 1982). Los números entre corchetes que en ella aparecen remiten a la paginación del texto árabe. 
hombre castaño, cejijunto y con mucho pelo a quien con embelecos llevan al templo, donde le desnudan y le meten en una pileta llena de manteca de sésamo que le llega hasta la garganta, y le tapan de manera que la cabeza quede fuera; luego pegan la tapa con plomo y le queda fuera la cabeza y el cuerpo en la manteca. Entonces le alimentan con higos pasos macerados en aceite de sésamo, determinada cantidad al día, y le sahúman al lado de la nariz con una mezcla (sahumerio del estupor le llaman), diciendo fórmulas suyas; durante cuarenta días y sin darle agua. Lo que le ocurre en la manteca es que se le aflojan los nervios y se le debilitan las articulaciones y le medran las venas y se pone blanco como la cera. Así preparado, se reúnen un día alrededor suyo, le dicen las fórmulas mentadas, le sahúman y le cogen de la cabeza y tiran desde la primera vértebra y se llevan también las venas, que están ligadas con aquéllas; salen todas las vértebras y lo demás del cuerpo se queda en la manteca. En esto le asientan en una olla sobre ceniza tamizada, que sacan de ceniza de aceituna y un poco de la ceniza de los cuerpos incinerados, y le cubren de algodón de colores y le sahúman con una mezcla suya y la cabeza les da detalles sobre el alza y baja de precios, el derrocamiento de los estados y cuanto sucede en el mundo. Los ojos siguen viendo, nada más que no parpadean, y cuando descuidan los ritos de los astros se los reclama y les reprende por cosas y les dice lo que va a pasar, e incluso si le preguntan por las artes y las ciencias les responde. Por fin sacan el despojo del cuerpo de la pileta, le extraen el hígado, lo interpretan y ven en él señales que necesitan. Igual los omóplatos y el juego de las articulaciones, por las que se guían cuando es preciso. Sólo se cortan el pelo, comen y beben en su nombre. En tiempos de al-Muqtadir fueron descubiertos y aquél mandó que entraran en sus capillas. Entonces se encontró la cabeza allí y cuando la hubieron extraído del ara ordenó su entierro» (14).

Las semejanzas de este relato con cierta clase de ficción occidental moderna (llámese de aventuras o de terror) es evidente. Por un lado pensamos en Poe; por otro en películas como Los estranguladores de la India o El misterio del templo maldito. El elemento diferenciador se percibe también de inmediato: los relatos occidentales se insertan en el espacio de la ficción (utilicen datos reales o no), entendida como objetivación de lo imaginario, y el rasgo que más profundamente los caracteriza es la presencia de un sujeto. El texto árabe, por su parte, se afirma como relación rigurosa de hechos reales, relación indiferente a la idea de sujeto; en los relatos occidentales los hechos giran en torno a un personaje individualizado y modélico; en el relato árabe individuos anónimos se insertan en los hechos o se deducen de ellos.

Otra dimensión diferencial es la del tiempo, entendido como atributo de la persona o no. La inserción de los hechos en el curso de la Historia que en el relato de Gãyat al-hakīm supone la mención de al-Muqtadir es sólo un modo más de garantizar la verdad de la acción como parte de la historia; de nuevo con un a modo de isnäd.

(14) al-Muqtadir fue el décimo octavo califa 'abbasī. Gobernó del año 295 (908) al 320 (932) y su reinado se caracterizó por la inestabilidad política. Su muerte fue violenta, al hacer frente a un general rebelde. 
Fuera de esto, al no individualizar su personaje, el autor sitúa la acción en un solo plano temporal, que es la sucesión objetiva. La precisión "cuarenta días» es un dato científico ajeno a la persona (el tiempo que tardan en aflojarse las articulaciones dentro del sésamo). Un escritor moderno, interesado en la emoción personal de los hechos y no en la veracidad de éstos, habría articulado la acción en un mínimo de tres personajes homólogos: dos iniciales, relativamente impersonales, que sufrirían el proceso y cuya experiencia facilitaría el triunfo del último personaje, éste plenamente individual. Fingiéndose víctima fácil acabaría por desarticular las siniestras actividades de los sacerdotes y por ponerlos en manos del poder. La función de éste es idéntica en el relato árabe medieval y en su supuesta versión actual: una instancia superior que sanciona el mal y defiende el bien. La presencia de los tres personajes y sus peripecias paralelas y diferentes aporta dos dimensiones temporales: una exterior y sucesiva y otra interior y alterna a compás con la experiencia del personaje.

Los escritores árabes medievales conocieron el personaje individual y lo usaron en obras de semi ficción, biográficas, sociológicas, o plenamente ficticias. ¿Por qué, entonces, no lo usó el autor de Gāyat al-hakīm? La respuesta es clara: atribuyendo los hechos a la experiencia de un personaje imaginario la materia del relato se convertía en ficción y descendía de la categoría superior de relato que era el jabar a la desdeñada de jurāfa. $Y$ ya hemos visto que el modelo del literato árabe medieval era más científico que artístico; su aspiración, fijar y transmitir fragmentos del mundo, noticias de la naturaleza y de lo humano. Sólo siendo trasunto verbal de lo cierto adquiría la obra legitimidad; de otro modo quedaba reducida al espacio más elemental, más infantil, el que consistía en encadenar fantásticas respuestas a la pregunta infatigable: "¿qué pasó luego?» (15).

La fuerza legitimadora de la verdad explica la presencia de invenciones espectacularmente imaginativas en obras muy alejadas de la jurāfa. Escudado en la noción de verdad (hechos ciertos respaldados por el Creador) el artista podía dejar libre su inventiva, pues sabía que en tal caso creaba sencillamente el correlato objetivo de ideas difíciles de captar a fondo de otro modo. Entre las muchas páginas admirables de esta clase destacan las dedicadas a la huríes:

"La médula de sus piernas se ve detrás de sus vestidos, y el que mira ve su rostro en el hígado de una de ellas como en un espejo» (16). "Su carne es tan delicada y tan fina que deja entrever sus músculos parecidos a hilos pasados en rubí; incluso cuando ellas llevan setenta vestidos, su tejido es tan

(15) Cfr. E. M. Forster, Aspects of the Novel (Penguin, Harmondsworth 1975, pp. 33-49). En la p. 35 Forster toma como modelo Las mil y una noches.

(16) La belleza como transparencia está ya en un hadīt, cfr. Bujārī Sahỉh, 59-8, 6. Versión francesa de G. $\mathrm{H}$. Bousquet, L'authentique Tradition musulmane (Sindbad, París 1986, V, 55, p. 104). "Tendrá dos esposas tan bellas que a través de la carne de las piernas alcanzará a vérseles la médula de los huesosn. La transparencia como suma belleza aparece en el Tirant lo blanc: "Por su garganta veía pasar el vino» (Alianza editorial, Madrid 1969 p. 109; cap. 29; trad : J. F. Vidal Jové). 
fino y su peso tan ligero que se entrevé la blancura resplandeciente y la belleza de sus piernas". "En su cabeza hay cien trenzas y entre cada una de esas trenzas hay setenta mil moñas, las cuales son más brillantes que la luna llena. Además, cada moña está coronada con perlas y abundantes joyas» (17).

Algo necesariamente invisible, aunque real, se materializa en apariencias que desbordan las habituales sobrepasando toda noción de verosimilitud y produciendo la fascinación y la extrañeza de las mejores creaciones surrealistas. El mensaje, por otra parte, es claro y sencillo y la proliferación de fantasías no lo oscurece mas lo ilumina: «Supera cuanto puedas imaginar o concebir».

En este punto conviene preguntar: ¿qué queda en la narrativa árabe actual de todo esto? Instinto para la autenticidad, es la respuesta.

Los numerosos relatos de al-Ŷ̀ăhiz en el Kitāb al-bujalā'se caracterizan por ser ilustración de ideas, lo cual hace que la inventiva quede estricta e intencionadamente limitada, para que nada estorbe la claridad impecable de la doctrina moral. Los relatos de al-Y̌ăḥiz̨ participan de la tipología del mațal lcreación de modelos de comportamiento) y del jabar (refiere hechos extraídos de la biografía de distintas personas) y su ambición es constituirse en hadịt, más aún que por la amenidad por construir un cuerpo de enseñanzas profanas tan impecables en su terreno como el hadit profético lo es en el sagrado. Puede decirse entonces que al-Ŷāhiz reduce sus narraciones desalojando de ellas cualquier rasgo (ambiental, psicológico, dramático...) susceptible de distraer al lector de las virtudes y vicios aplaudidos o afeados. Lo que impulsa a al-Ŷāhiz̨ es la voluntad de adquirir y transmitir la verdad en su sentido más estricto; no se trata nunca, de ningún modo, de la verdad poética, que es, según venimos entendiéndolo desde el siglo XVI, la propia de la literatura narrativa. Nada más ajeno a al-Ŷāhiz que "el principio de incertidumbre, propio de la novela moderna» (18). Todos los relatos que este escritor aduce en su obra los aduce porque han sucedido verdaderamente y porque contienen una enseñanza verdadera. Lo que busca al-Ŷăhiz̧ es hacer literatura científica, transmitir autenticidad en la forma accesible a la palabra: la narración.

En el Kitāb al-bujalā' al-Ŷāhiz hace el inventario y proporciona ejemplo, amonestación o aviso contra todas las formas de avaricia; todas las formas reales; pues la avaricia no es una idea, sino una práctica con la que el individuo se inserta en la realidad. El libro contiene, no obstante, algunos relatos de los que era imposible desalojar los elementos ajenos a la única y principal intención, ya que hacerlo habría supuesto que el relato resultara ininteligible.

Los dos casos más interesantes son: 1) el de los hermanos que habían

(17) Traducción de Concepción Castillo en "La 'huríes' en la tradición musulmana" (lll Jornadas de Cultura Arabe e Islámica, IHAC, Madrid, mayo de 1983). Publicado en M.E.A.H., XXIV-XXXV (1985-1986). pp. 7-18. Lo citado en pp. 10-11.

118) Carlos Fuentes, "Arthur Lundkvist: "El viaje del sueño y la fantasía», en "Culturas», n. ${ }^{\circ} 177(1 / 10 / 88)$, p. 1. 
puesto su patrimonio en común, y 2) la historia de Iumāma y Qāsim (19). Voy a reproducir y a comentar el primero:

"Me contó al-Mišrī, vecino de ad-Dārdurīš̄, cuya fortuna era incontable, lo siguiente:

Cierta vez echó a un pordiosero estando yo delante; $y$ más tarde corrió a otro, pero de mala manera, con rabia. Dirigiéndome a él le comenté:

- No hay nada más odioso para ti que los mendigos.

-Porque la mayoría de esos que ves tienen más que yo.

-No creo que los odies por eso.

- Todos ésos, si pudieran, demolerían mi casa y me arrancarían la vida y si yo les obedeciera y diese cada vez que me piden sería idéntico a ellos desde hace tiempo. ¿Qué puedes pensar entonces de mi odio para los que tan mal me quieren?

Su hermano era también su socio en todo. Incluso en la avaricia se le parecía. Un día viernes el hermano nos ofreció - estábamos a su puertauna bandeja con dátiles frescos, que en Basora vienen a costar dos dāniq; mientras comíamos llegó el otro, que ni saludó ni habló nada, metiéndose en la vivienda. Nosotros censuramos tal comportamiento, pues solía excederse siempre mostrando una alegría que de paso le servía para proteger sus dineros, pues sabía que, de juntar cicatería y orgullo, casi se le habría dado muerte. Ni nosotros ni su hermano sabíamos cuál era la razón de aquella actitud.

Al viernes siguiente, el hermano volvió a invitar a una bandeja de dátiles. En tanto comíamos salió el otro de la casa sin pararse ni saludar. Le censuramos por esto, pero no sabiamos a cuento de qué venía aquéllo.

Al tercer viernes - en que nos volvió a ver en la misma ocasión- escribió a su hermano: "Hermano mío, la asociación entre nosotros conlleva no tener muchos hijos porque cuando éstos proliferan aparecen las rencillas y no estoy cierto de que los míos y los tuyos no terminasen perpretrando algo indigno. Mas he aquí que hay riquezas a mi nombre, cuya mitad tú detentas y otras a la inversa; tenemos bienes en metálico en mi casa y en la tuya sin que sepamos dónde hay mayor cantidad. Si el mandamiento divino llama a nuestra puerta (si fallecemos) ocurrirá una guerra sin tregua entre esos hijos e interminables jaleos entre las mujeres. Mi opinión es que desde el día de hoy hemos de acabar con las posibles causas (de desavenencia)».

Cuando el hermano leyó el escrito lo consideró preocupante e incluso aterrador. Dio vueltas a la cuestión por arriba y por abajo, pero de tales laberin-

(19) Libro de los avaros (trad. cit., pp. 190-192 y 256-258 respectivamente). 
tos no sacó luz alguna. Así pues, recurrió a sus hijos y les habló con dureza: "Quizá alguno de vosotros cometiera cualquier error con una palabra; o tal vez esta desgracia es culpa de las mujeres». Una vez se cercioró de la inocencia de toda la familia se fue al otro, descalzo y a pie, y le dijo:

- ¿A qué se debe que quieras dividir y hacer partijas? Llama inmediatamente a los hombres más santos de la mezquita para que los tome por testigos de mi buena administración en cuanto se refiere a propiedades; llévate a tu casa cuanto hay en la mía y comprueba en el acto mi actuación. Si encuentras que defraudo o me aprovecho en algo, obra a tu voluntad, pero ahora necesito que me notifiques cuál es mi falta.

- No hay falta ninguna, sin embargo no queda más remedio que dividir.

El demandante quedó con él repitiéndole la misma cantilena hasta medianoche, sin cesar de hacer promesas y rogar. Como la cosa se iba alargando en demasía, cansado ya el hermano le dijo:

- Háblame de esas bandejas de dátiles que ofreces, de esas esteras que extiendes en la vía pública, del agua fresca que haces traer, de las personas que reúnes a mi puerta cada viernes. Parece como si me creyeras tan ciego como para no darme cuenta de semejantes liberalidades. Si hoy les alimentas con dátiles gordos y de calidad, mañana será con los dulces y pasado con los del país. Más adelante tal conducta se generalizará de los viernes a todos los días de la semana. De los dátiles se pasará a los almuerzos; de los almuerzos a las cenas y de éstas a las ropas, los cabritos y corderos y por último a los regalos. Por Dios que lamentaría tal destino para la hacienda del Estado y los tributos territoriales del reino, ¿qué no he de pensar de los dineros de un comerciante que los juntó cobre a cobre, pieza a pieza, moneda a moneda?

- Te lo juro: si quieres que no vuelvan jamás a comer dátiles u otra cosa lo haré. Y por añadidura nunca más les he de hablar.

- Cuidado con errar dos veces: la primera alimentándolos a tu costa y la segunda granjeándote su enemistad. Sal de este asunto en la misma forma en que entraste: obedéceme y estarás a salvo".

Varios elementos de este relato escapan a la estricta transmisión de los datos y a la ilustración rígida de la idea. Elementos ambientales (los convites a la puerta: «esas esteras que extiendes en la vía pública, esa agua fresca que haces traer, esas bandejas"), relacionales (la tensión que impone el hermano con sus pasadas en silencio por entre los que comen), psicológicos (la relación de dominio entre los hermanos: "obedéceme y estarás a salvo»), dramáticos (el rigor con que el hermano estrictamente avaro maneja la avaricia vacilante del otrol. La definición e ilustración de la avaricia no impide, pues, que la mención de realidades laterales, relativas al paso del tiempo en lo fundamental, contribuya a crear un espacio narrativo caractericado no sólo por la verdad sino también por la verdad poética. La ficción, sin embargo, sí es rigu- 
rosamente desalojada del texto (ningún dato da lugar a suposiciones imaginarias; todos trabajan unívocamente en la exposición de un implacable mecanismo de causas y efectos). Por ello la impresión que produce el relato de al-Ŷăhiz es de crónica, en el sentido en que lo eran las ficciones neorrealistas; de otro modo, es decir, con más voluntad de enriquecer el espacio ficticio, estaríamos ante un esperpento (20).

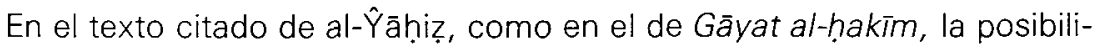
dad de desarrollar los elementos de ficción implícitos fue desatendida en favor de otra que los autores consideraron de un interés superior y más perdurable. Si no profundizaban en lo que constituye la base de la narrativa moderna (tiempo, espacio y persona; ejemplaridad poética, conceptualización implícital es porque no querían. Preferían centrarse, por ejemplo, en la estructura, una estructura que ha popularizado Las mil y una noches y ha recibido el nombre de enmarcada o en cajas chinas. Consiste en trabajar con dos o más relatos (aspectos de la realidad) entrelazados, incompleto el inicial (los iniciales) hasta que concluye el central, el único que va narrado sin interrupciones. Supuesta una unidad de tres cuentos este tipo de estructura narrativa podría esquematizarse así:

\section{$1(2$ (3) 2) 1}

O bien, si quiere respetarse el carácter circular que indudablemente tiene, de este otro modo:

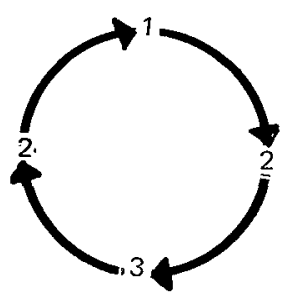
(Claves: 1: emisor-receptor representados en el rey Dib- xalim y el sabio Paydeba. 2: Cuento conductor, «EI asceta y el viajero". 3: Cuento intercalado: «El cuervo que quiso andar como la perdiz»l.

En esta forma de narrar el binomio emisor/receptor queda netamente diferenciado del mensaje. Emisor/receptor aparecen en el relato inicial/final (1), con frecuencia mero pretexto para plantear el tema; el relato inicial enlaza el tema con una manifestación problemática (2); el relato final le da solución (3). En el libro de Calila y Dimna, que es la obra donde he visto desarrollada esta disposición formal de modo más puro, 1 , son los diálogos del rey Dibxalim y el sabio Paydeba; 2, por ejemplo, el apólogo del asceta y el viajero; 3 , el del cuervo que quiso andar como la perdiz (21).

(20) Otros relatos del Kitāb al-bujalä́, que contienen datos ambientales de gran vitalidad, donde conviven sin posible escisión verdad de vida, verdad de concepto y verdad poética en las pp. 172, 190 y 258 260 de la traducción citada.

(21) En el capítulo titulado «El asceta y el viajero». El de "La paloma collarada» enlaza hasta cinco relatos. El de "El león y el buey" reitera múltiples veces la estructura de tres elementos (que asi parece lineal), pasando en una ocasión a cinco. 
No hay que olvidar, por otra parte, que el hadīt profético es a su vez una estructura de tres elementos que se enlazan tarŷūma: tema; isnād: inserción en la realidad; matn: texto) y que en él el binomio emisor/receptor queda plenamente al margen del texto.

Si examinamos la Rihla de Ibn Bațūtata veremos que se trata de un relato de formación inserto en un relato de itinerario (22). Itinerario y formación reales; a diferencia de los textos modernos de este tipo Ibn Bațūța no plantea idealmente el proceso de formación ni especula sobre su futuro posible, sino que relata cómo fue el proceso de su formación como hombre a lo largo de un largo viaje.

En la Rihla de Ibn Bațtūṭa tenemos a grandes rasgos dos tipos de relato:

1) El del itinerario, encuentros e incidentes que ponen a prueba y forman al narrador.

2) Narraciones al margen, con mayor componente ficticio, que el narrador ofrece como jalones en su conocimiento de lo que en los mundos sobrepasa las expectativas del hombre. Ibn Bațtuța es con frecuencia sujeto de estas narraciones y se muestra perfectamente natural aun cuando los incidentes sean fantásticos o poco comunes (23).

Los textos que pertenecen al apartado 1 tienen forma de crónica o diario y se caracterizan por la progresiva franqueza: aproximadamente hasta la mitad del viaje (cuando visita Bizancio) Ibn Batțūța no se refiere nunca a relaciones afectivas (fuera de la triste despedida de sus padres) o sexuales; ni a ningún tipo de gusto. A partir de ese momento, sin embargo, hace mención de ello en todas las etapas del viaje. Es un aspecto ya señalado por la crítica. pero que no se agota fácilmente, tal es su riqueza (24). Hacia la parte final, estas menciones aúnan una gran sencillez de expresión con una gran implica: ción personal; trátese de amores o de gustos:

«Repudié a la mujer a la cual concediera un plazo por estar preñada $y$ mandé a por una joven esclava que me gustaba mucho" (25).

"De la raíz de estos últimos (ñames) hacen harina, con la que preparan una especie de fideos que cuecen en leche de coco: es uno de los mejores platos que conozco, del que comí abundantemente, pues me gustaba muchísimo» (26).

122) Las letras alemanas modernas son las iniciadoras del género y las que le han dado nombre, bildungsroman. Enrique de Ofterdingen, de Novalis, es una de las obras pioneras.

(23) Cfr. el caso de telepatía em las pp. 706-707 de la trad. de Serafín Fanjul y Federico Arbós, A través del Islam (Editora Nacional, Madrid 1981).

(24) Cfr. pp. $415,425,450,578,582,596,631,638,655,660,661,663,677,681,683,703,789$ de la trad. cit.

(25) Id., p. 681.

(26) Id., p. 663 . 
A pesar de esto, para la norma del relato moderno lbn Bațūta es un testigo demasiado impasible. En ocasiones parece desconfiar de la propia mirada (si no es que había olvidado lo visto). Esta actitud es agudamente perceptible en las descripciones de lugares prestigiosos: como si se sintiera inferior a ellos o a quienes los habían descrito antes que él, Ibn Bațūta opta por reproducir textos ajenos o se escuda en frases hiperbólicas hechas. Sólo a la hora de transmitir datos muy precisos demuestra sus cualidades de observador y su gusto por la exactitud (27).

Tomemos la descripción de la mezquita de la Roca, en Jerusalén, que conjuga los dos extremos, vaguedad hiperbólica al principio, exactitud al final (28). Puestas en paralelo las intervenciones de una y otra clase se reparten así:

\begin{tabular}{|c|c|}
\hline DATOS CONCRETOS & EXPRESIONES VALORATIVAS \\
\hline 1. Es un edificio & $\begin{array}{l}\text { 1. Portentoso. } \\
\text { Perfecto. } \\
\text { Sorprendente. } \\
\text { Porción de hermosura. } \\
\text { Tomó algo de cada maravilla. }\end{array}$ \\
\hline \multicolumn{2}{|l|}{$\begin{array}{l}\text { 2. Se alza sobre una elevación. } \\
\text { Se sube por una escalinata. }\end{array}$} \\
\hline $\begin{array}{l}\text { 3. Rotonda e interior pavimenta- } \\
\text { dos con mármol. }\end{array}$ & 3. Perfecta ejecución. \\
\hline $\begin{array}{l}\text { 4. Dentro y fuera, varias clases de } \\
\text { adorno. }\end{array}$ & $\begin{array}{l}\text { 4. Espléndidos. } \\
\text { Imposible describirlos. }\end{array}$ \\
\hline $\begin{array}{l}\text { 5. La mayor parte recubierta de } \\
\text { oro. Reluce. }\end{array}$ & $\begin{array}{l}\text { 5. Como perla de luz. } \\
\text { Con la intensidad del relámpago } \\
\text { La vista se ciega. } \\
\text { La lengua humana es incapaz } \\
\text { de describirlo. }\end{array}$ \\
\hline \multicolumn{2}{|l|}{$\begin{array}{l}\text { 6. En medio del templete está la } \\
\text { Roca: sólida, de una braza de } \\
\text { altura. }\end{array}$} \\
\hline $\begin{array}{l}\text { 7. Bajo la Roca hay una cavidad, } \\
\text { como un cuarto pequeño, de } \\
\text { una braza. Se baja por una es- } \\
\text { calera. }\end{array}$ & \\
\hline \multicolumn{2}{|l|}{ 8. Dentro hay un mihrab. } \\
\hline $\begin{array}{l}\text { 9. La Roca está cercada por dos } \\
\text { rejas, que la guardan. Una de } \\
\text { hierro; la otra, de madera. }\end{array}$ & $\begin{array}{l}\text { 9. Perfectamente hechas. } \\
\text { De factura maravillosa (29). }\end{array}$ \\
\hline
\end{tabular}

127) No olvido que la Riḥla se redactó en la vejez de lbn Bațțuta y sin (o sin apenas) documentación personal. Pero no creo pertinente poner este dato por encima de la orientación formal.

(28) Descripciones que despliegan una extraordinaria exactitud son la de la mezquita de los omeyas de Damasco (ed. cit., pp. 182-186) y la de La Meca (id., pp. 224-225).

(29) Trad. cit. p. 153 y s. Cuando se trata de describir con textos ajenos Ibn Bațtüta recurre sobre todo a lbn Ŷ́ubayr. 
Los textos que pertenecen al apartado 2 muestran que lbn Bațūța tiene perfectamente interiorizada la precepti : califica de jurāfa todo relato mágico o mítico (así el que incluye sobre el origen del cocotero, recogido en la India) (30), salvo que la verdad lo legitime. Por ejemplo el referente a la ubicuidad de las pp. $250 / 251$ de la trad. citada, moderno en su manejo de lo maravilloso pero ajeno al concepto moderno de narración por la distancia al personaje principal y el desentendimiento respecto a las posibilidades emotivas de la acción. Lo que impulsa el relato es, como hemos visto en casos anteriores, transmitir un caso de ubicuidad auténtico.

Pero por lo general los relatos de la Rihla de Ibn Bațtuța son puntuales y están ligados a alguna pasión del ánimo (avaricia, deseo, afán de poder, ansia). Su intención es ejemplar y en ningún momento los enfoca el autor como experiencia total en el destino del individuo, ni siquiera cuando la materia es una acción que lo marcará definitivamente (31). Por lo demás dos cosas llaman la atención en ellos: su variedad y las curiosas concomitancias que ofrecen con otros relatos antiguos y modernos (32).

Para el propósito que ahora me ocupa examinaré uno que refiere un hecho de historia política y se centra a la vez en expresar un destino individual (33).

Como en los dos ejemplos estudiados anteriormente contiene los datos necesarios para insertarse en la realidad ( De lo acontecido en la ciudad de Alejandría el año 727-1326-7 de J. C. nos llegó noticia en La Meca y es lo siguiente») y tener garantía de autenticidad:

"Acaeció una disputa entre los musulmanes y los comerciantes cristianos siendo valí de Alejandría un hombre conocido por al-Karaki que vino en salvaguardar a los cristianos y mandó presentarse a los musulmanes entre los dos baluartes de la puerta de la ciudad e hizo cerrar los batientes tras ellos para castigarlos. Esto no fue del agrado de la gente por parecerles desmedido, así pues, rompieron la hoja y se revolvieron contra la residencia del gobernador, que se fortificó para defenderse de ellos, mientras los combatía desde lo alto y enviaba palomas mensajeras con la noticia a al-Malik an-Nāṣir. Éste remitió a un emir llamado al-Ŷamālĩ. Luego, le hizo seguir por otro conocido por Tagwān, hombre orgulloso y cruel sobre cuya fe religiosa había dudas, pues se decía que adoraba al sol. De este modo entraron en Alejandría, apre-

(30) Trad. cit., p. 355. Gāyat al-hakīm refiere varias recetas mágicas a base de enterrar semillas de plantas dentro de calaveras (Cfr. tratado IV, cap. 7, p. 404 de la trad. cit.), igual que en lo que cuenta lbn Batțüta.

(31) Esto atañe especialmente a los fragmentos de vidas de santos que inciuye. Véase, por ejemplo, el de la p. 130 y el de la p. 214. También la historia de Adham en las pp. 173-174.

(32) El relato de la p. 214 es casi idéntico a otro de la Risālat al-quds, de Ibn 'Arabī; el del hombre que vendió una esclava y luego enloqueció por no poder tenerla (p. 790) a otro de Tawq al-hamama, de lbn Hazm; el del avaro de las pp. 552-552 parece sacado del Kitāb al-bulalā'; el apasionante de seducción y desvío de la p. 130 coincide con un momento de Pero... ¿hubo alguna vez once mil vírgenes?, de Jardiel Poncela (3. "parte, 4, 18; pp. $466-469$ de la ed. de Luis Alemany, Cátedra, Madrid 1988).

(33) Trad. cit. p. 124 
saron a los más principales de sus habitantes y a los mercaderes cabecillas (...) y les arrancaron muchos dineros. También se colocó al cuello del cadí Imād al-Dīn un cepo metálico. Más adelante ambos emires ejecutaron a $\mathbf{3 6}$ hombres descuartizándolos, tras lo cual fueron crucificados en dos hileras. Esto ocurrió un viernes y como las gentes salieran después de rezar, según su hábito, a visitar los cementerios, contemplaron la matanza con lo que creció su pena, redoblándose sus tristezas. Entre aquellos crucificados se encontraba un comerciante muy capaz llamado Ibn Rawha que tenía una estancia dispuesta con armas y cuando quiera que se daba una causa de alarma o zafarrancho preparaba con qué armar a uno o dos centenares de hombres. En la ciudad había numerosos almacenes de este jaez. Su lengua hizo resbalar a Ibn Rawha, porque manifestó a los emires: "Soy garante de esta ciudad y siempre que suceda cualquier hecho en ella, que se me pida. Evitaré al sultán los dispendios de soldada de tropas». Los emires no gustaron de sus palabras por lo que respondieron: "Tú pretendes alzarte contra el sultán". Y le dieron muerte, sin embargo su intención no era otra que mostrar su adhesión y deseo de servir al sultán, lo que fue causa de su fin».

A diferencia de los dos relatos comentados antes éste tiene todos los componentes que exige la normativa moderna: un personaje central, resumen y modelo de la acción, en relación conflictiva con ella y determinado o individualizado en todos los aspectos centrales del relato (aquí psicológicos, sociales y políticos); una acción que se modula a partir del personaje individualizado y de su contraste con otros, a los que se relaciona complementaria o problemáticamente. En un solo punto se aparta este relato de la normativa moderna: la exposición de los hechos no es progresiva, sino simplemente sucesiva: no avanza hacia un clímax sino hacia la completa exposición de todos los datos del caso. Resulta así neutra, pero no porque el autor se abstenga, como opción de estilo, de opinar o identificarse a la acción (de hecho lbn Batṭuu ța deplora el destino de Ibn Rawha y desaprueba a su oponente; además, condena por equivocada la política del valí, causa del relatol sino porque sitúa y expone las diversas incidencias a idéntico nivel y concediéndoles idéntico espacio; no sabe ni quiere saber ni sugerir más de lo que dice (llenando espacio narrativo a la actividad contraria). La razón de ello es que a lbn Baț̣u ta, como a los autores de los dos textos anteriormente comentados, lo que le importa es dar noticia y dar ejemplo. Es decir, no concibe la actividad narrativa como un proceso de seducción sino como un proceso de conocimiento; no como la creación de un objeto de placer sino como la creación de un objeto edificante.

Lo que los componentes narrativos de la Rihla de Ibn Bațūța aporten a la narrativa árabe actual depende de las combinaciones y variaciones que sean capaces de inspirar. En su caso no hay incitaciones a la imaginación desbordada, pero sí materiales ricos en vida condensada, que son los que forman sus noticias, susceptibles de alimentar nuevas formas de realismo. Pero éstas dependen por entero de la capacidad de síntesis y la tendencia de los escritores de hoy. 
Las formas de relato cultivadas en árabe en tiempos pasados no dejan de serlo por ajustarse a principios que no son los que guían la narrativa moderna; ésta, por otro lado, no surge de la nada, según algunos estudiosos parecen afirmar (34), sino de una nueva sensibilidad y, en consecuencia, de un nuevo modo de organizar materiales preexistentes. El estudio detallado de las formas narrativas árabes antiguas sería de positiva utilidad a la narrativa actual, ya que los últimos intentos de renovación de ésta han seguido caminos paralelos a los de aquélla: el relato objetivo proponiéndose percibir lo humano en las cosas; la novela ensayo subordinado al sentido la acción... Aquí está la clave, quizá, del malentendido: la narrativa árabe del pasado siempre prefirió la verdad a la impresión de realidad. al-Muwaylihĩ era muy consciente de

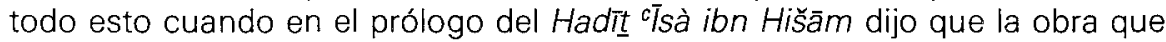
alí comenzaba era: "verdad engalanada con el ropaje de la imaginación (jayâll), no imaginación fundida en el molde de la verdad» (35).

(34) Abdel-Aziz Abdel-Meguid, op. cit., p. 73

(35) Edición citada, p. 22. Véase también Muhammad al-Marzūqi, Ahãdît as-samar (ad-Dār at-tūnisìya li-nnašr, Túnez 1984, pp. 5-61. 